\title{
MONKS AND ICON PAINTERS FROM THE SPASO-ANDRONIKOV MONASTERY, MOSCOW
}

\author{
E I Alexandrovskaya ${ }^{1} \cdot$ A L Alexandrovskiy $^{1} \cdot \mathrm{J}_{\text {van der Plicht }}^{2,3} \bullet \mathrm{N} \mathrm{N} \mathrm{Kovalyukh}^{4} \bullet$ \\ V V Skripkin ${ }^{4}$
}

\begin{abstract}
In the Monastery of Our Saviour and St. Andronicus in Moscow, skeletal remains of clerics and of (possibly) famous icon painters were discovered. The bones were radiocarbon dated, and concentrations of trace elements in bone tissues were measured. From tombs $1-4$, the ${ }^{14} \mathrm{C}$ dates obtained from human bones (likely monks) and from associated wood date to the 14th-15th centuries AD, as expected. Trace element concentrations indicate signs of fasting. Tomb 5 contained 2 burials; these could belong to the famous icon painters Rublev and Chernyi. Indeed, the bones show high concentrations of lead, zinc, and copper, which is typical for remains of artists and metallurgists. The ${ }^{14} \mathrm{C}$ dates of the 2 skeletons, however, differ by $200 \mathrm{yr}$, and seem to be too old for Rublev and Chernyi. At this stage, it is not clear if the burials can be assigned to these painters.
\end{abstract}

\section{INTRODUCTION}

Fossil bones can provide information on the living conditions of people from the past. Concentrations of trace elements in bone tissues of ancient people can be used to obtain information on their diet (e.g. Gilbert 1977; Kozlovskaya 1996). Our studies of human remains, ranging from the Paleolithic Age to the Medieval epoch and using the determination of a great number of elements in human bone tissues, showed that the elemental composition of the latter depends on diet, drinking water, and economic activity. This field of science, anthropochemistry, studies the chemical interaction between activities of humans and their environment (Alexandrovskaya and Alexandrovskiy 2003, 2005).

Radiocarbon dating provides the age of the bones, but the interpretation can be problematic because of contamination with allochtonous carbon or because of a dietary reservoir effect. ${ }^{14} \mathrm{C}$ dating and trace elemental analysis of human bone tissues are used together to investigate the skeletal remains of 6 humans buried in 5 tombs, excavated in the Saviour Cathedral of the Monastery of Our Saviour and St. Andronicus (Spaso-Andronikov Monastery) in Moscow (Figure 1). This study is of great historical importance, because it is possible that 2 outstanding early Russian icon and fresco painters, Andrei Rublev and Daniil Chernyi, are buried in tomb number 5 (in the upper and lower burial, respectively). It is known that these painters spent the last years of their lives in this monastery, where they both died in AD 1430 (Encyclopaedia Britannica, 2008). The tombs were excavated during 1993-94 (tombs 1-4) and 2003 (tomb 5). Unfortunately for ${ }^{14} \mathrm{C}$ dating purposes, the bones were treated with wax and incense as preservatives following their excavation (personal communication in 2006 with V Savinykh, Archpriest, superior of Spasski Cathedral).

The aim of our work is (1) to perform ${ }^{14} \mathrm{C}$ dating of the 6 persons buried in the 5 tombs in the cathedral, taking into account the contamination by preservatives, and (2) to study the trace elemental composition of the bone tissues in terms of the social and professional status of the buried individuals.

\footnotetext{
${ }^{1}$ Institute of Geography, Russian Academy of Sciences, Moscow, Russia.

${ }^{2}$ Center for Isotope Research, Groningen University, Groningen, the Netherlands.

${ }^{3}$ Faculty of Archaeology, Leiden University, Leiden, the Netherlands. Corresponding author. Email: J.van.der.Plicht@rug.nl.

${ }^{4}$ Institute of Environmental Geochemistry, Ukraine Academy of Science, Kiev, Ukraine.
} 


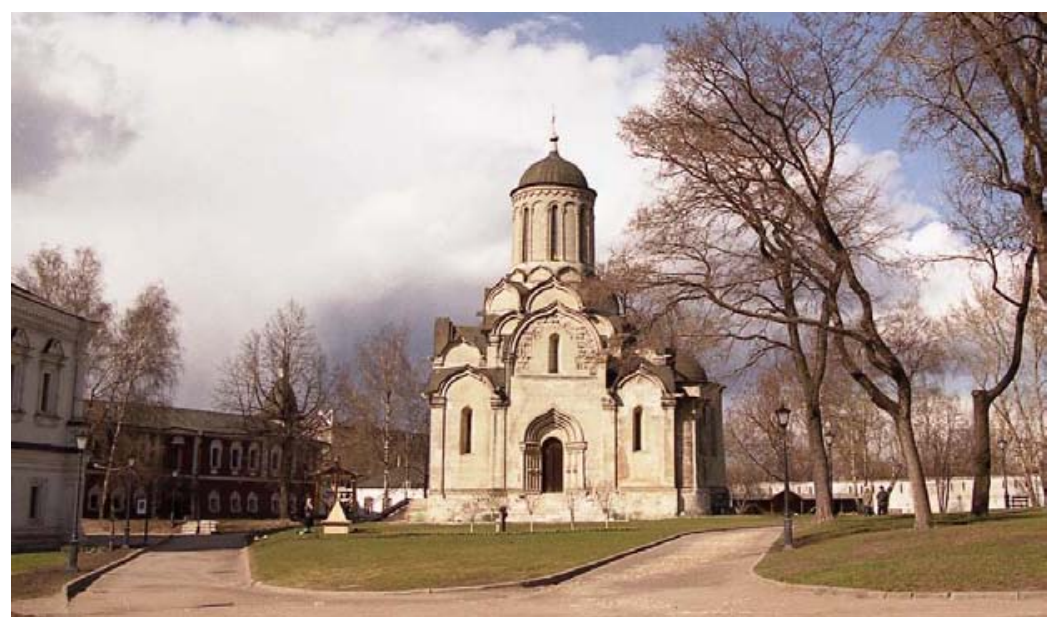

Figure 1 The Saviour Cathedral of the St. Andronicus Monastery in Moscow

\section{MATERIALS AND METHODS}

\section{Radiocarbon}

The human bone material from all 5 tombs in the Saviour Cathedral has been investigated. The excavation site in the cathedral is shown in Figure 2. The numbers 1-5 in the photograph correspond to the different tombs. Bone tissues and wood of coffins from tombs $1-4$ were dated by ${ }^{14} \mathrm{C}$. The larger samples of wood were dated conventionally by liquid scintillation counting in Kiev (laboratory code $\mathrm{Ki}$ ). The small samples (bone and wood) were dated by accelerator mass spectrometry (AMS) in Groningen (laboratory code GrA). In addition, the ${ }^{14} \mathrm{C}$ content of the preservatives applied to the bone samples has been measured by AMS.

The human bones were all treated with a mixture of wax and incense. This contamination was removed by the Soxleth procedure at the Radiocarbon Laboratory in Kiev, using 2 types of solvents. The samples were placed in fiberglass containers. In the first step, a mix of benzene-ethanol (ratio 1:1) was used. The samples were first boiled for $24 \mathrm{hr}$, and then dried at a temperature of $100{ }^{\circ} \mathrm{C}$ in vacuum. In the second step, the samples were washed in chloroform for $12 \mathrm{hr}$, and then dried.

Also, some wood from the coffins was contaminated with the same substance. For a thorough cleaning, crushed wood fragments were treated with diluted (1-3\%) hydrofluoric acid. The amorphous silica was dissolved, leaving the wood fibers intact. After drying the sample at $120^{\circ} \mathrm{C}$, the organic carbon was transformed into lithium carbide by vacuum pyrolysis (Skripkin and Kovalyukh 1998).

From the bone samples, collagen was extracted as the datable fraction in Groningen using a modernized version of the Longin method (Longin 1970). The collagen was combusted, purified, and transferred into graphite (Aerts-Bijma et al. 2001). The graphite is pressed into target holders for the ion source of the AMS. The AMS then measures the isotope ratios ${ }^{14} \mathrm{C} /{ }^{12} \mathrm{C}$ and ${ }^{13} \mathrm{C} /{ }^{12} \mathrm{C}$ of the graphite, from which the conventional ${ }^{14} \mathrm{C}$ age is determined (van der Plicht et al. 2000).

\section{Trace Element Analysis}

X-ray fluorescent analysis (XRF) enables the analysis of unique materials from archaeological and other collections without their destruction. Concentrations of trace elements in bone tissues can be measured and used for anthropochemical reconstructions (Alexandrovskaya and Alexandrovskiy 


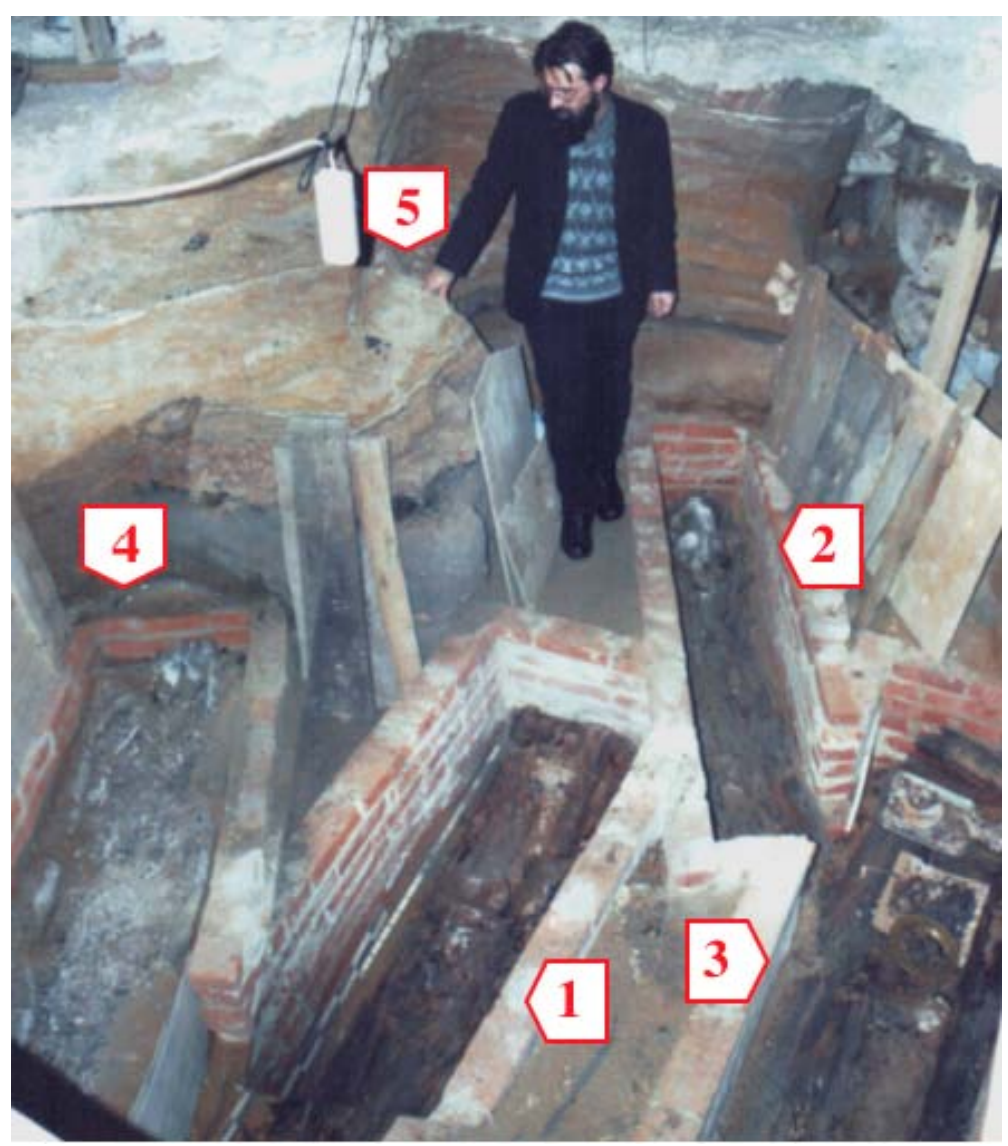

Figure 2 Tombs (numbered 1-5) excavated in the Saviour Cathedral, St. Andronicus Monastery.

2005). The wide range of analyzed elements is a distinctive feature of the method. Diet reconstructions are based on the study of a relatively small (usually 4) number of elements (Gilbert 1977; Kozlovskaya 1996). We have used a TEFA-III (ORTEC) energy-dispersive XRF machine.

\section{RESULTS AND DISCUSSION}

\section{Radiocarbon}

The ${ }^{14} \mathrm{C}$ dates of the bones and wood fragments from tombs 1-4 are shown in Table 1 . They are in good agreement. The results show that the contamination of wax and incense on the bones has been adequately removed. Two wood samples (fragments of coffins, indicated with * in Table 1 ) were also contaminated with wax and incense. These wood fragments were found in tombs 2 and 3 . The results of the ${ }^{14} \mathrm{C}$ dating showed that the wood was also adequately cleaned, so that the difference in the ${ }^{14} \mathrm{C}$ ages of the wood impregnated with wax and incense and the initially "clean" wood is negligible (see Table 1). The ${ }^{14} \mathrm{C}$ dates are calibrated using the calibration curve IntCal04 (Reimer et al. 2004). ${ }^{14} \mathrm{C}$ dates are shown with their $1-\sigma$ measurement errors. The calibrated date ranges shown are the corresponding $1-\sigma$ intervals. 
Table $1{ }^{14} \mathrm{C}$ dates for the materials found in tombs $1-5$ of the Saviour Cathedral. The bone samples and wood marked with * were impregnated with wax and incense (see text).

\begin{tabular}{|c|c|c|c|c|c|c|}
\hline Tomb & Sample & Lab code & $\begin{array}{l}\text { Age } \\
\text { (BP) }\end{array}$ & $\begin{array}{l}\text { Date, cal AD } \\
(1 \sigma)\end{array}$ & $\begin{array}{l}\delta^{13} \mathrm{C} \\
(\%)\end{array}$ & $\begin{array}{l}\delta^{15} \mathrm{~N} \\
(\%)\end{array}$ \\
\hline \multicolumn{7}{|l|}{ Wood } \\
\hline 1 & $\begin{array}{l}\text { Maple (Acer), } \\
\text { outer rings }\end{array}$ & Ki-13184 & $755 \pm 50$ & $1225-1281$ & $\mathrm{n} / \mathrm{a}$ & $\mathrm{n} / \mathrm{a}$ \\
\hline 1 & $\begin{array}{l}\text { Maple (Acer), } \\
\text { middle rings }\end{array}$ & Ki-13182 & $805 \pm 45$ & $\begin{array}{l}1193-1196 \\
1208-1270\end{array}$ & $\mathrm{n} / \mathrm{a}$ & $\mathrm{n} / \mathrm{a}$ \\
\hline 1 & $\begin{array}{l}\text { Maple (Acer), } \\
\text { inner rings }\end{array}$ & Ki-13228 & $840 \pm 35$ & $\begin{array}{l}1165-1227 \\
1233-1239 \\
1248-1251\end{array}$ & $\mathrm{n} / \mathrm{a}$ & $\mathrm{n} / \mathrm{a}$ \\
\hline 1 & Maple (Acer) & GrA-34192 & $705 \pm 35$ & $\begin{array}{l}1267-1298 \\
1372-1377\end{array}$ & -25.82 & $\mathrm{n} / \mathrm{a}$ \\
\hline 2 & Oak (Quercus) & Ki-13188 & $645 \pm 50$ & $\begin{array}{l}1286-1319 \\
1351-1390\end{array}$ & $\mathrm{n} / \mathrm{a}$ & $\mathrm{n} / \mathrm{a}$ \\
\hline 2 & Oak (Quercus) & GrA-34061 & $640 \pm 40$ & $\begin{array}{l}1290-1318 \\
1352-1390\end{array}$ & -27.15 & $\mathrm{n} / \mathrm{a}$ \\
\hline 2 & Oak (Quercus)* & GrA-34055 & $585 \pm 35$ & $\begin{array}{l}1314-1357 \\
1388-1406\end{array}$ & -25.57 & $\mathrm{n} / \mathrm{a}$ \\
\hline 3 & $\begin{array}{l}\text { Oak (Quercus), } \\
\text { middle rings }\end{array}$ & Ki-13185 & $850 \pm 50$ & $\begin{array}{l}1059-1063 \\
1155-1258\end{array}$ & $\mathrm{n} / \mathrm{a}$ & $\mathrm{n} / \mathrm{a}$ \\
\hline 3 & $\begin{array}{l}\text { Oak (Quercus), } \\
\text { outer rings }\end{array}$ & Ki-13183 & $690 \pm 50$ & $\begin{array}{l}1269-1309 \\
1361-1386\end{array}$ & $\mathrm{n} / \mathrm{a}$ & $\mathrm{n} / \mathrm{a}$ \\
\hline 3 & Oak (Quercus) & GrA-34062 & $660 \pm 35$ & $\begin{array}{l}1284-1309 \\
1361-1386\end{array}$ & -26.70 & $\mathrm{n} / \mathrm{a}$ \\
\hline 3 & Oak (Quercus)* & GrA-34056 & $620 \pm 35$ & $\begin{array}{l}1298-1324 \\
1345-1372 \\
1378-1393\end{array}$ & -24.93 & $\mathrm{n} / \mathrm{a}$ \\
\hline 4 & $\begin{array}{l}\text { Oak (Quercus) of } \\
\text { poor preservation }\end{array}$ & Ki-13187 & $645 \pm 40$ & $\begin{array}{l}1286-1319 \\
1351-1390\end{array}$ & $\mathrm{n} / \mathrm{a}$ & $\mathrm{n} / \mathrm{a}$ \\
\hline 4 & Oak (Quercus) & GrA-34077 & $575 \pm 35$ & $\begin{array}{l}1316-1354 \\
1389-1411\end{array}$ & -24.81 & $\mathrm{n} / \mathrm{a}$ \\
\hline \multicolumn{7}{|l|}{ Bones } \\
\hline 1 & - & GrA-34439 & $640 \pm 50$ & $\begin{array}{l}1288-1321 \\
1349-1391\end{array}$ & -20.70 & $\mathrm{n} / \mathrm{a}$ \\
\hline 3 & - & GrA-34051 & $710 \pm 40$ & $\begin{array}{l}1263-1298 \\
1370-1379\end{array}$ & -19.94 & 12.04 \\
\hline 4 & - & GrA-34187 & $620 \pm 35$ & $\begin{array}{l}1298-1324 \\
1345-1372 \\
1378-1393\end{array}$ & -20.27 & 11.64 \\
\hline 5 & Upper burial & GrA-34054 & $700 \pm 40$ & $\begin{array}{l}1268-1300 \\
1368-1381\end{array}$ & -19.43 & 11.83 \\
\hline 5 & Lower burial & GrA-33847 & $900 \pm 50$ & $\begin{array}{l}1045-1097 \\
1119-1142 \\
1147-1188 \\
1198-1206\end{array}$ & -21.56 & $\mathrm{n} / \mathrm{a}$ \\
\hline - & wax + incense & GrA-34189 & $\begin{array}{l}\text { modern } \\
(116 \%)\end{array}$ & - & -26.62 & $\mathrm{n} / \mathrm{a}$ \\
\hline
\end{tabular}


Most dates correspond to the time interval ranging from AD 1270 to 1390 (see Figure 3). A few dates obtained for wood, as well as 1 bone date, are somewhat older. The older date obtained from the wood found in tomb 1 can be explained by the admixture of material from heartwood to the dated tree rings because of the poor degree of preservation of these wood fragments.

The date for the bone from the upper burial in tomb 5 is $700 \pm 40 \mathrm{BP}$ (GrA-34054); the calibrated age interval $(1 \sigma)$ is AD 1270-1300 and 1370-1380. The oldest interval (AD 1270-1300) has the highest probability (80\%), which makes the date somewhat older than the time of the construction of the Saviour Cathedral. The date from the lower skeleton, $900 \pm 50$ BP (GrA-33847), is even 2 centuries older.

Traces of contamination (remaining even after our rigorous pretreatment) cannot explain an older age for the bones from tomb 5 . We have dated the mixture of the preservative, wax plus incense that had been applied to the bones. The ${ }^{14} \mathrm{C}$ age for this material is modern; the measured ${ }^{14} \mathrm{C}$ activity is $116 \%$ (GrA-34189). Thus, traces of incompletely removed contamination of this material cannot explain a possible offset in the older direction.

The conservation circumstances of the bones in tomb 5 were not ideal. In particular, the bones from the lower burial showed signs of degradation. However, the ${ }^{14} \mathrm{C}$ quality parameters for the bones dated are acceptable.

Human bones can show reservoir ages of a few centuries because of a significant portion of fish in the diet (e.g. Shishlina et al. 2007). For a number of human bones including the upper burial of tomb 5 , we measured the stable isotope ratios $\delta^{13} \mathrm{C}$ and $\delta^{15} \mathrm{~N}$ for the bone collagen (see Table 1).

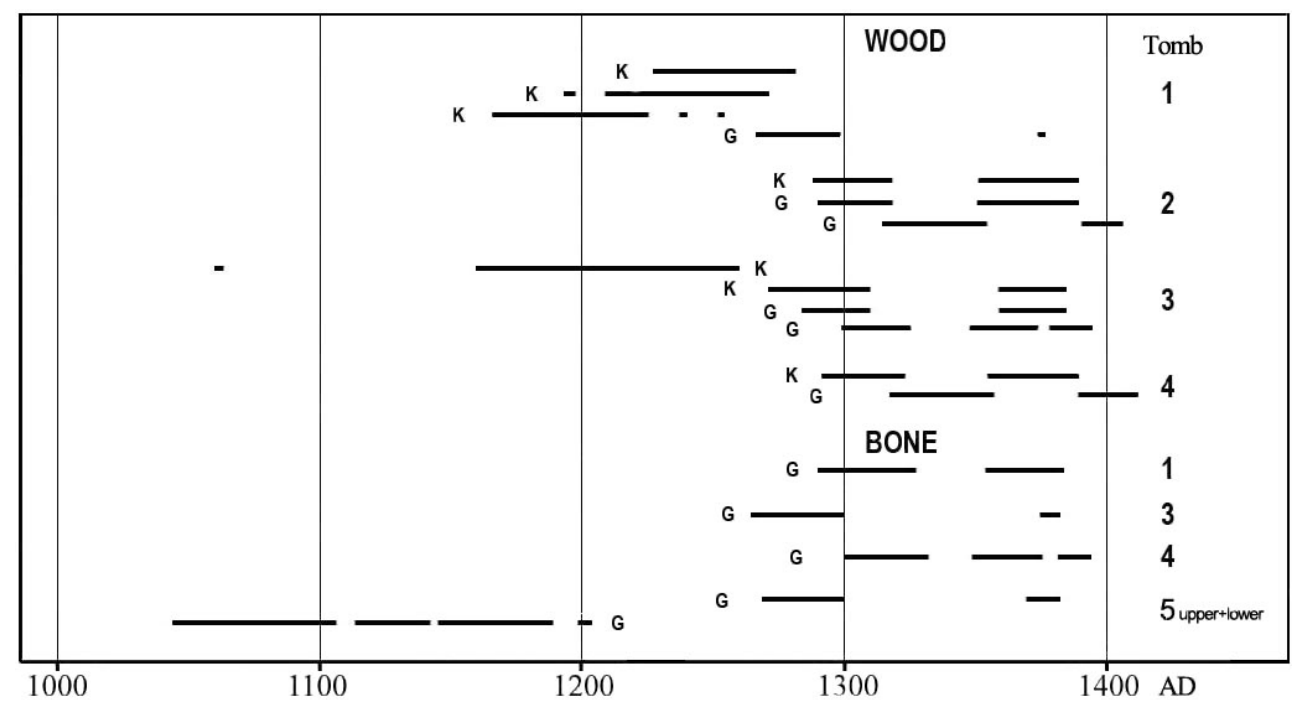

Figure 3 Overview of calibrated age intervals for wood and bone samples from the Saviour Cathedral, measured by Groningen (G) and Kiev (K).

Based on the $\delta^{15} \mathrm{~N}$ values for bone from the Donau Gorge determined for diets based on terrestrial food and freshwater fish (Cook et al. 2001), there is little room for a significant reservoir effect causing apparent ${ }^{14} \mathrm{C}$ ages. 
Table 2 Trace elements in soil samples. The concentrations are given in $\mathrm{mg} / \mathrm{kg}$ soil; the so-called Clarke values are given in a relative scale according to Emsley (1991). Concentrations in bold are higher than the Clarke values.

\begin{tabular}{lrrrrrrrrrr}
\hline Sample & $\mathrm{Ni}$ & $\mathrm{Cu}$ & $\mathrm{Zn}$ & $\mathrm{Ga}$ & $\mathrm{Hg}$ & $\mathrm{As}$ & $\mathrm{Br}$ & $\mathrm{Pb}$ & $\mathrm{Rb}$ & $\mathrm{Sr}$ \\
\hline Clarke value & 99 & 30 & 76 & 15 & 0.5 & 2 & 0.7 & 13 & 78 & 384 \\
St. Andronicus, soil A1 (0-1) & 4 & 10 & 51 & 6 & $\mathbf{3}$ & $\mathbf{1 0}$ & 0 & 7 & 38 & 83 \\
St. Andronicus, buried soil & 7 & 12 & 29 & 6 & $\mathbf{3}$ & $\mathbf{9}$ & 0 & 4 & 11 & 34 \\
\hline
\end{tabular}

For the lower burial, unfortunately, not enough sample material was available to measure both carbon isotope ratios $\delta^{13} \mathrm{C}$ and $\delta^{14} \mathrm{C}$, and $\delta^{15} \mathrm{~N}$ as well. It is historically known that fish is one of the food sources of Russian monks (Stepasheva 1991). Finally, we note that reburial of the skeletons cannot be excluded. Thus, the ${ }^{14} \mathrm{C}$ age of the bones from tomb 5 require further investigation, from both the archaeological and scientific perspective.

\section{Anthropochemistry}

The trace elemental composition of soil samples from the layer corresponding to burials $1-4$ and soil from within the cathedral are shown in Table 2. Particularly noticeable are elevated concentrations of mercury and arsenic. This can be explained by the use of mercury-based paints applied to the walls of the cathedral; in particular, cinnabar might have been used (Art Press 1948). In addition, arsenic-based paints could have been used as well. Many paints also contain increased concentrations of zinc and lead. The source of zinc in soils and artist bones can be isinglass, used for the fabrication of icons.

This observation is supported by the measurements of fragments of painted plaster consisting of different colors. These fragments are taken from the air duct in the chancel part of the Saviour Cathedral (see Table 3). It is known that such paints were used by fresco and icon painters of Rublev's time. As an illustration, the famous icon "Trinity" made by Rublev is shown in Figure 4.

Table 3 Concentrations of iron (in \%) and trace elements $\left(n \times 10^{-6}\right)$ in fragments of painted plaster from the chancel part of the Saviour Cathedral.

\begin{tabular}{|c|c|c|c|c|c|c|c|c|c|c|}
\hline Sample & Fe, \% & Mn & $\mathrm{Ni}$ & $\mathrm{Cu}$ & $\mathrm{Zn}$ & $\mathrm{Pb}$ & As & $\mathrm{Hg}$ & $\mathrm{Sr}$ & Supposed pigment \\
\hline 1 grayish pale & 1.7 & 50 & 6 & 13 & 15 & 10 & 1.0 & 5.0 & 750 & Cinnabar \\
\hline 2 yellowish-reddish & 2.2 & 50 & 6 & 30 & 100 & 10 & 2.5 & 160 & 1100 & Cinnabar \\
\hline 3 gray & 1.7 & 50 & 7 & 14 & 20 & 25 & 1.5 & 0.5 & 1000 & ? \\
\hline gray & 0.1 & 25 & 4 & 430 & 10 & 20 & 4.0 & 0.5 & 750 & Cop \\
\hline 5 pale re & 0.6 & 40 & 8 & 20 & 120 & 15 & 4.0 & 250 & 600 & hd orpiment \\
\hline 6 orange & 2.7 & 50 & 18 & 25 & 20 & 60 & 1.0 & 0.5 & 1200 & Red lead (minimum) \\
\hline $7 \mathrm{gr}$ & 2.8 & 20 & 3 & 35 & 7 & 10 & 0.8 & 0.5 & 700 & ? \\
\hline $8 \mathrm{pi}$ & 0.6 & 45 & 15 & 30 & 15 & 10 & 1.5 & 17 & 700 & Cin \\
\hline $9 \mathrm{da}$ & 6.6 & 60 & 10 & 25 & 15 & 987 & 1.0 & 0.5 & 700 & Red lead with ochre \\
\hline $\begin{array}{l}10 \text { gray-pink; } \\
\text { traces of } \mathrm{Br} \text { and } \mathrm{Cr}\end{array}$ & 0.6 & 35 & 7 & 30 & 25 & 10 & 4.0 & 20 & 1200 & Cinnabar and orpiment \\
\hline $11 \mathrm{gra}$ & 0.4 & 80 & 5 & 00 & 7 & 97 & 1.0 & 0.5 & 1000 & Ма \\
\hline 12 gray-pink & 5.5 & 50 & 5 & 7 & 15 & 30 & 1.0 & 13 & 1000 & Cinnabar and red lead \\
\hline
\end{tabular}

The geochemical environment affects human health through the foodchain and drinking water. But the concentration of certain trace elements, such as lead, zinc, copper, arsenic, and mercury in human bodies can also be associated with human professional activities. 
Table 4 Concentrations of iron (in \%) and trace elements $\left(n \times 10^{-6}\right)$ in bone tissues. Clarke values are given in a relative scale according to Emsley (1991). Concentrations in bold are higher than the Clarke values.

\begin{tabular}{|c|c|c|c|c|c|c|c|c|c|c|}
\hline Sample & Fe, \% & $\mathrm{Mn}$ & $\mathrm{Ni}$ & $\mathrm{Cu}$ & $\mathrm{Zn}$ & $\mathrm{Pb}$ & As & $\mathrm{Hg}$ & $\mathrm{Sr}$ & $\mathrm{Br}$ \\
\hline Clarke value & 1.5 & 10 & 0.7 & 1.8 & 14 & 1.9 & 0.1 & 0.04 & 8.5 & 0.7 \\
\hline Tomb 1 & 0.19 & 21 & 0.9 & 0.2 & 26 & 0.2 & 0.3 & 0.04 & 11.4 & 0.1 \\
\hline Tomb 2 & 0.14 & 17 & 0.2 & 0.9 & 9.5 & 0.0 & 0.4 & 0.10 & 11.1 & 0.2 \\
\hline Tomb 3 & 0.61 & 6 & 1.4 & 1.4 & 19 & 0.2 & 0.4 & 0.10 & 7.7 & 0.1 \\
\hline Tomb 4 & 0.01 & 9 & 0.1 & 0.5 & 45 & 0.5 & 0.2 & 0.06 & 12.3 & 0.0 \\
\hline \multicolumn{11}{|c|}{ Tomb 5, chancel part of the Saviour Cathedral, Upper skeleton } \\
\hline Cuneiform bone & 0.9 & 9.0 & 0.7 & 0.9 & 38 & 25 & 0.1 & 0.03 & 30 & 0.5 \\
\hline Phalange & 0.6 & 1.4 & 0.7 & 2.9 & 48 & 6 & 0.1 & 0.04 & 35 & 0.5 \\
\hline Colla & 0.9 & 4.5 & 1.2 & 1.6 & 36 & 2 & 0.1 & 0.02 & 50 & 0.3 \\
\hline Vertebr & 1.2 & 6.0 & 1.0 & 2.5 & 55 & 18 & 0.2 & 0.03 & 40 & 0.4 \\
\hline Humerus & 1.9 & 11 & 0.5 & 2.5 & 68 & 10 & 0.1 & 0.03 & 52 & 0.4 \\
\hline \multicolumn{11}{|l|}{ Lower skeleton } \\
\hline Cunei & 0.8 & 8.0 & 0.6 & 2.0 & 60 & 15 & 0.2 & 0.03 & 35 & 0.5 \\
\hline Vertebra & 1.3 & 1.4 & 2.5 & 2.5 & 42 & 10 & 0.2 & 0.03 & 40 & 0.5 \\
\hline
\end{tabular}

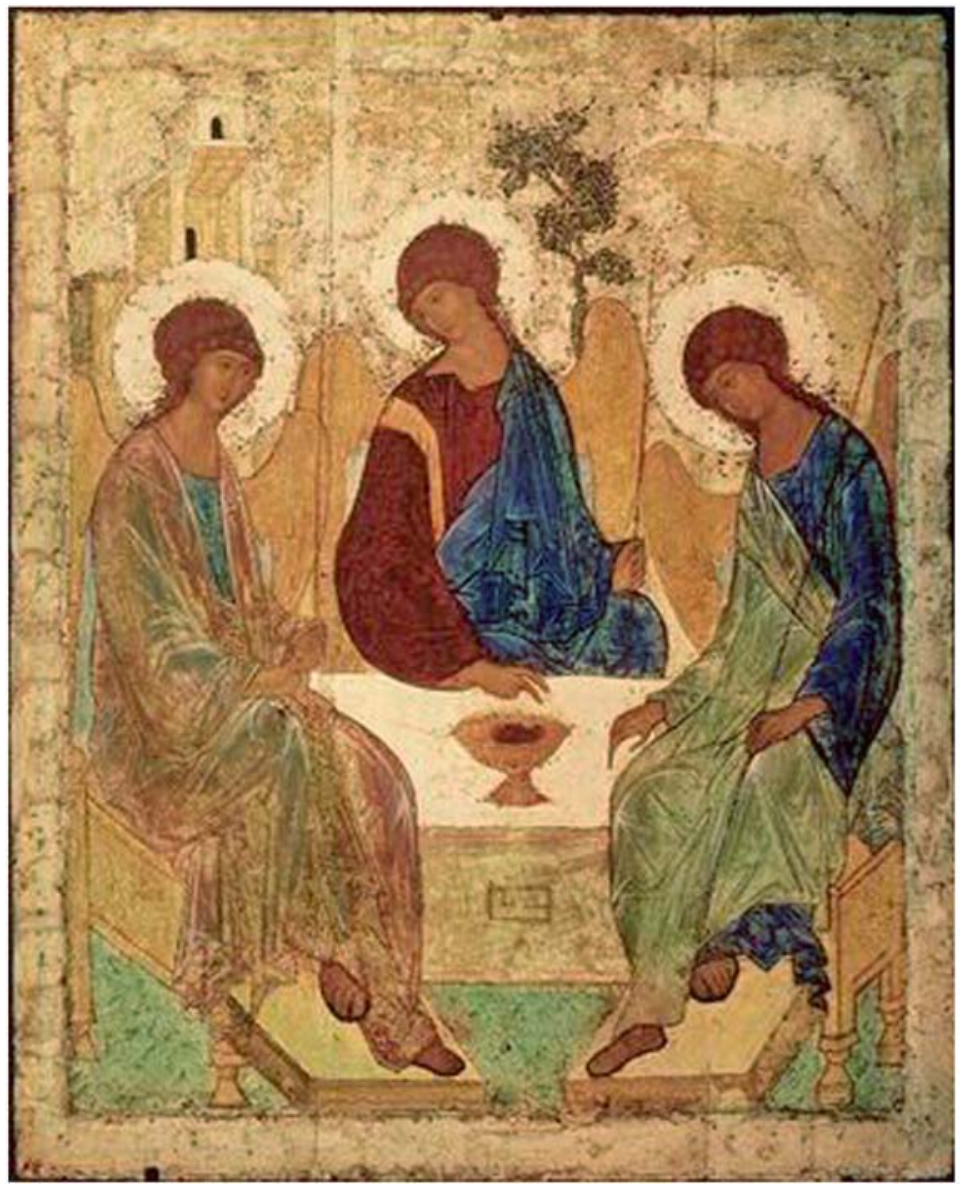

Figure 4 The icon “Trinity” by Andrei Rublev 
Iron is of great significance for the physiology of humans, as it is the major catalyst of respiration processes. About $57 \%$ of iron in human bodies is present in hemoglobin. Among other human organs, the liver and spleen are also rich in iron. The iron concentrations in the bones from tombs 14 are relatively low, which is an indication of exhaustion or of hemorrhage. In the bones from tomb 5 , the iron content is close to normal. On the other hand, these bones show an increased concentration of zinc, which can be related to a specific diet (like a predominance of oats, peas, or fish) and/ or to their professional occupation. Increased zinc concentrations are typical for people working in metallurgy, as the smelting of many metals is usually accompanied by the emanation of zinc. The zinc concentration can also be increased in the bodies of painters, because some paints are characterized by a high zinc content.

Increased content of zinc is also observed in the bone material from tomb 4; the lead concentration is in the normal range. Bones from tomb 3 show slightly increased values of arsenic, possibly due to mushrooms. These were widely used as a food source (Stepasheva 1991). Bones from tombs 2 and 3 show an increase in the content of mercury, probably caused by the use of medicine (Alexandrovskaya and Alexandrovskiy 2005).

Lead-based paints-white, yellow, orange, and red-were widely applied during the Medieval epoch. In the bones from tombs 1-4, the concentration of zinc is relatively low, so we can assume that these people did not work with lead-based paints. The elevated concentration of zinc is found in the bones from tomb 5, so we consider it likely that these people were in contact with such paints.

To summarize, our anthropochemical study suggests that the bones of people from tombs 1-4 are depleted in many trace elements, whereas the bones of people buried in tomb 5 are enriched in a number of trace elements. The low concentration of iron and copper in the bones from tombs 1-4 can be an indication for anemia.

In the bones of the people buried in tomb 5, the iron concentration is close to normal, whereas the concentrations of zinc and lead are increased. This can be explained by the fact that these people worked in metallurgy or in the painting business. In theory, the increased concentration of zinc could also be caused by a considerable portion of fish in the diet.

Thus, the ${ }^{14} \mathrm{C}$ dates of the bones of people buried in tomb 5 differ strongly, whereas the anthropochemical data show large similarities, indicating that the bones belonged to artists. The carbon content of the collagen for GrA-34054 and GrA-33847 was 43 and 30\%, respectively, which is good to acceptable. Also, the $\delta^{13} \mathrm{C}$ values and $\mathrm{C} / \mathrm{N}$ ratios (where possible) are in the normal range. These are the main quality parameters for bone collagen. There is therefore no reason not to accept the dates from the laboratory point of view (Mook and Streurman 1983). The unexpected old ${ }^{14} \mathrm{C}$ date for the lower burial in tomb 5 requires further investigation.

\section{CONCLUSION}

The skeletal remains of 6 humans found buried in the Saviour Cathedral of the St. Andronicus Monastery in Moscow are of great historical importance, since the first clerics of the monastery and famous icon painters were probably buried there. The determination of the age of burials by ${ }^{14} \mathrm{C}$ was somewhat problematic, because following the excavation, all the bones were treated with a mixture of wax and incense. The contaminant showed a modern ${ }^{14} \mathrm{C}$ age $\left({ }^{14} \mathrm{C}\right.$ activity $\left.116 \%\right)$ and could be removed by the Soxleth procedure. This special pretreatment proved effective.

The concentration of trace elements and iron in the bones showed that the chemical composition of the bones found in tombs 1-4 (in wood coffins) differed from that of the bones found in tomb 5 . In 
tombs 1-4, bone tissues were depleted in iron and copper, suggesting that these people suffered from exhaustion and anemia. The bones from tomb 5 show increased concentrations of many trace elements, but there is no indication of exhaustion of these people. The data suggest that the diet and professional occupation of these 2 persons were identical, but different from the persons buried in tombs $1-4$. This strongly suggests that they were metallurgists or artists.

The ${ }^{14} \mathrm{C}$ measurements show that burials $1-4$ date to the end of the 13th into the 14th centuries AD. The dual burial in tomb 5 yields different dates. The date obtained from the bones of the upper burial is close to the expected age (the 14th century). At this stage, it is not clear if the burials can be assigned to the painters Rublev and Chernyi. The lower burial especially requires further investigation, both from the historical as well as the isotopic point of view.

\section{REFERENCES}

Aerts-Bijma AT, van der Plicht J, Meijer HAJ. 2001. Automatic AMS sample combustion and $\mathrm{CO}_{2}$ collection. Radiocarbon 43(2A):293-8.

Alexandrovskaya EI, Alexandrovskiy AL. 2003. Historic-Geographical Anthropochemistry. Moscow: NIA-Priroda. 204 p. In Russian.

Alexandrovskaya EI, Alexandrovskiy AL. 2005. Radiocarbon data and anthropochemistry of ancient Moscow. Geochronometria 24:87-96.

Art Press. 1948. Fresco and Tempera Painting: The Material and Technology of Russian Mural Painting, 11th-17th Centuries. Art Press, issue 2, Moscow-Leningrad. 448 p. In Russian.

Cook GT, Bonsall C, Hedges REM, McSweeney K, Boroneant V, Pettitt PB. 2001. A freshwater diet-derived ${ }^{14} \mathrm{C}$ reservoir effect at the Stone Age sites in the Iron Gates Gorge. Radiocarbon 43(2A):453-60.

Emsley J. 1991. The Elements. Oxford: Clarendon Press. $256 \mathrm{p}$.

Encyclopaedia Britannica. 2008. Chicago: Encyclopaedia Britannica, Inc.

Gilbert R. 1977. Applications of trace elements research to problems in archaeology. In: Blakely RL, editor. Biocultural Adaptations in Prehistoric America. Athens: University of Georgia Press. p 85-100.

Kozlovskaya MV. 1996. Ecology of Ancient Tribes in the Forest Zone of Eastern Europe. Moscow: Greko-Latinskii kabinet. 244 p. In Russian.

Longin R. 1970. Extraction du collagène des os fossiles pour leur datation par la méthode du carbone $14[\mathrm{PhD}$ dissertation]. University of Lyon.

Mook WG, Streurman HJ. 1983. Physical and chemical aspects of radiocarbon dating. In: Proceedings of the First Groningen Symposium on C14 and Archaeology. PACT 8:31-55.

Reimer PJ, Baillie MGL, Bard E, Bayliss A, Beck JW, Bertrand CJH, Blackwell PG, Buck CE, Burr GS, Cutler KB, Damon PE, Edwards RL, Fairbanks RG, Friedrich M, Guilderson TP, Hogg AG, Hughen KA, Kromer B, McCormac G, Manning S, Bronk Ramsey C, Reimer RW, Remmele S, Southon JR, Stuiver M, Talamo S, Taylor FW, van der Plicht J, Weyhenmeyer CE. 2004. IntCal04 terrestrial radiocarbon age calibration, 0-26 cal kyr BP. Radiocarbon 46(3):1029-58.

Shishlina NI, van der Plicht J, Hedges REM, Zazovskaya EP, Sevastianov VS, Chichagova OA. 2007. The Catacomb culture of the Northwest Caspian steppe: ${ }^{14} \mathrm{C}$ chronology, reservoir effect and paleodiet. Radiocarbon 49(2):713-26.

Skripkin VV, Kovalyukh NN. 1998. Recent developments in the procedures used at the SSCER Laboratory for the routine preparation of lithium carbide. $R a-$ diocarbon 40(1):211-4.

Stepasheva I. 1991. The Monastic Kitchen. Moscow: Union of Russian Writers Press. 64 p. In Russian.

van der Plicht J, Wijma S, Aerts AT, Pertuisot MH, Meijer HAJ. 2000. The Groningen AMS facility: status report. Nuclear Instruments and Methods in Physics Research B 172(1-4):58-65. 